\title{
Different clinical aspects of debrancher deficiency myopathy
}

Stefan Kiechl, Ursula Kohlendorfer, Claudia Thaler, Daniela Skladal, Michaela Jaksch, Bert Obermaier-Kusser, Johann Willeit

\begin{abstract}
Objective-To characterise the main clinical phenotypes of debrancher deficiency myopathy and to increase awareness for this probably underdiagnosed disorder. Methods-The diagnosis of debrancher deficiency was established by laboratory tests, EMG, and muscle and liver biopsy. Results-Four patients with debrancher deficiency myopathy were identified in the Tyrol, a federal state of Austria with half a million inhabitants. Clinical appearance was highly variable. The following phenotypes were differentiated: (1) adult onset distal myopathy; (2) subacute myopathy of the respiratory muscles; (3) severe generalised myopathy; and (4) minimal variant myopathy. Exercise intolerance was uncommon. The clinical course was complicated by advanced liver dysfunction in two patients and by severe cardiomyopathy in one. All had raised creatine kinase concentrations (263 to $810 \mathrm{U} / 1$ ), myogenic and neurogenic features on EMG, and markedly decreased debrancher enzyme activities in muscle or liver biopsy specimens. The findings were substantiated by a review of 79 previously published cases with neuromuscular debrancher deficiency.

Conclusions-This study illustrates the heterogeneity of neuromuscular manifestations in debrancher deficiency. Based on the clinical appearance, age at onset, and course of disease four phenotypes may be defined which differ in prognosis, frequency of complications, and response to therapy.

(F Neurol Neurosurg Psychiatry 1999;67:364-368)
\end{abstract}

Keywords: glycogenosis; glycogen storage disease; debrancher deficiency; myopathy

Debrancher deficiency (glycogenosis type III, Cori-Forbes disease ${ }^{12}$ ) is a glycogen storage disease with predominantly hepatic and neuromuscular phenotypes and an autosomal recessive mode of inheritance. ${ }^{3}$ The hepatic subtype presents in childhood with the typical clinical triad of hepatomegaly, growth retardation, and fasting hypoglycaemia. ${ }^{3}$ Phenotypic expression and age at onset of neuromuscular disease, by contrast, are highly variable. Previous surveys suggested classifications of type III glycogenosis based on the underlying biochemical defect and organ involvement ${ }^{4-6}$ or on the temporal sequence of liver and muscle disease. ${ }^{7}$ The cur- rent study focused on the various clinical aspects of debrancher deficiency myopathy.

\section{Methods}

ANALYSIS OF SKELETAL MUSCLE TISSUE

Histochemical reactions were carried out on $10 \mathrm{~m}$ thick, fresh frozen sections $\left(-70^{\circ} \mathrm{C}\right)$. Sections were stained with haematoxylin and eosin, periodic acid Schiff (PAS), modified Gomori trichrome, oil red O, Sudan black B, $\mathrm{NADH}$ tetrazolium reductase, succinate dehydrogenase, phosphorylase, and $\alpha$-glycerophosphate dehydrogenase. Fibre typing was based on the myofibrillar adenosine triphosphatase reaction at $\mathrm{pH} 9.4,4.6$, and 4.2. Muscle specimens for biochemical analysis were immediately frozen in liquid nitrogen. A minimum of 20 mg muscle tissue was homogenised in HEPES-EDTA buffer (1:20). Amylo-1,6glucosidase was determined according to the methods described by Hers et al in $1967,{ }^{8}$ with liberation of glucose from a phosphorylase limit dextrin. Measurements were done twice and average values given.

\section{ELECTROPHYSIOLOGY}

Electrophysiological examinations were all carried out on a Nicolet electromyograph (Vicking 4.0) and included nerve conduction studies (median, ulnar, peroneal, tibial, and sural nerves) and quantitative needle EMG

\section{Case reports}

The current study included four unrelated patients with debrancher deficiency myopathy. Age at disease onset ranged from 1 to 62 years. There were no inherited disorders or known consanguinity in the families of our patients. Laboratory findings are detailed in table 1.

\section{CASE 1}

This man was apparently healthy until the age of 62, when he became aware of slowly progressive muscle wasting of the calves and peroneal muscle groups. Polyneuropathy due to vitamin $\mathrm{B}_{12}$ deficiency ( $135 \mathrm{pmol} / \mathrm{l}$, normal $>148$ ) was suspected and vitamin substitution initiated. Muscle weakness, however, further deteriorated and spread to intrinsic hand and forearm muscles. Proximal limb regions remained spared. On admission to our hospital 4 years later his gait was unstable; walking on toes and heels was not possible. Muscle strength was 3/5 (Medical Research Council scale) in the tibialis anterior and triceps surae muscles and $4+/ 5$ in the forearm flexors and hand muscles. Deep tendon reflexes were 
Table 1 Laboratory findings in four patients with debrancher deficiency myopathy

\begin{tabular}{|c|c|c|c|c|c|}
\hline Variable & Patient 1 & Patient 2 & Patient 3 & Patient 4 & Normal \\
\hline Creatine kinase $(\mathrm{U} / \mathrm{l})$ & 424 & 410 & 810 & 239 & $\begin{array}{l}\text { Women }<80 \\
\text { Men }<140\end{array}$ \\
\hline Glutamic oxaloacetic transaminase $(\mathrm{U} / \mathrm{l})$ & 25 & 45 & 101 & 613 & $6-17$ \\
\hline Cholesterol (U/1) & 6.15 & 4.20 & 4.75 & 5.51 & $2.71-5.69$ \\
\hline $\begin{array}{l}\text { Abnormal response to glucagon } \\
\text { injection }\end{array}$ & NP & $\mathrm{NP}$ & + & + & \\
\hline Pathological exercise test & + & + & NP & NP & \\
\hline \multicolumn{6}{|l|}{ Echocardiography: } \\
\hline Cardiomyopathy & + & ++ & + & - & \\
\hline \multicolumn{6}{|l|}{ Nerve conduction study: } \\
\hline Reduced nerve conduction velocity & + & - & + & - & \\
\hline \multicolumn{6}{|l|}{ Electromyography: } \\
\hline Fibrillation activity & + & ++ & ++ & + & \\
\hline Myopathic features & ++ & ++ & ++ & + & \\
\hline Neurogenic features & + & + & + & + & \\
\hline \multicolumn{6}{|l|}{ Muscle biopsy: } \\
\hline Glycogen concentration (mg/g NCP) & 179 & 149 & 180 & NP & $60-105$ \\
\hline Amylo-1,6-glucosidase (U/g NCP) & 1.0 & 1.1 & NP & NP & $3.0-6.3$ \\
\hline Acid maltase (U/g NCP) & 2.0 & 2.0 & NP & NP & $1.2-3.5$ \\
\hline $\mathrm{N}$-acetyl-glucosaminidase (U/g NCP) & 4.3 & 3.3 & $\mathrm{NP}$ & $\mathrm{NP}$ & $2.6-5.4$ \\
\hline PAS Positive vacuolar myopathy & ++ & + & ++ & NP & \\
\hline $\begin{array}{l}\text { Cytoplasmatic glycogen pools in } \\
\text { electron microscopy }\end{array}$ & ++ & + & + & NP & \\
\hline Liver biopsy suggestive of GSD III & NP & ++ & ++ & ++ & \\
\hline
\end{tabular}

$\mathrm{NCP}=$ non-collagen protein; PAS=periodic acid Schiff; GSD=glycogen storage disease. $\mathrm{NP}=$ laboratory test not performed; $-=$ negative or absent; $+/++=$ evident or present (two categories).

decreased in the arms and absent in the feet. Sensation was normal. There was no clinical or laboratory evidence of liver dysfunction.

CASE 2

This woman had no history of childhood hepatomegaly or hypoglycaemia. She performed normal exercise until the age of 45, when exertional dyspnoea developed and cardiomyopathy was diagnosed. At the age of 47 she had an episode of major depression, refused nutrition, and steadily lost weight. She was admitted to hospital in a psychiatric clinic where she continued fasting but allowed substitution of vitamins and fluid. Within 2 days she developed respiratory failure with prominent hypercapnia and was intubated. She tolerated mechanical ventilation with marginal sedation, was able to get up and use her hands with normal skill, but was unable to breathe. Muscle strength was $4+/ 5$ in deltoid and biceps muscles, normal in other limb muscles, and markedly reduced in intercostal and auxiliary ventilatory muscles. After 2 weeks of controlled ventilation and no evidence of remission a high protein diet (30\%-35\% of total energy intake) was started. Within a period of 4 days she was successfully weaned from the respirator. Four months after discharge muscle strength and spirometry had normalised. Cardiomyopathy, however, further deteriorated.
CASE 3

In this patient, a 60 year old man, hepatomegaly and fasting hypoglycaemia were first noticed in childhood. Motor development and milestones were normal. The patient had always been intolerant to vigorous exercise, complained of action induced myalgia, and once experienced pigmenturia after a long lasting gastrointestinal infection. Symptoms tended to regress around puberty but again worsened during adult life. At the age of 53 he was admitted to our hospital because of a hypoglycaemic coma (blood glucose, 1.22 $\mathrm{mmol} / \mathrm{l})$. He had unstable angina pectoris and advanced heart failure. The liver extended 5 $\mathrm{cm}$ below the costal margin. At the age of 54 the patient developed progressive muscle wasting primarily affecting proximal limb and trunk muscles. One year later he could not rise from a chair without assistance. He stopped working and soon needed help to dress. Five years after onset of myopathy he could not hold his arms over his head and was wheelchair bound.

CASE 4

This male patient was admitted to our hospital at the age of 8 months on account of muscular hypotonia, hypoglycaemia, hepatomegaly, and delayed motor development. The diagnosis of glycogen storage disease type III was established by liver biopsy (debrancher enzyme 0 $\mathrm{nmol} / \mathrm{min} / \mathrm{mg}$ non-collagen protein, normal 0.3-2.0) and therapy with frequent feeds during the day, cornstarch supplementation, and continuous feeding via nasogastric tube overnight was started. Under this treatment the child showed no more hypoglycaemic attacks and gained normal weight. Height remained at the 3 rd percentile. Liver function improved. $\mathrm{He}$ learned to walk when he was 2 years old. Neurological examination at the age of 9 years showed mild proximal muscle weakness.

Table 2 depicts the frequency of the various clinical phenotypes in the literature $e^{9-27}$ and illustrates differences in the rates of nerve involvement, complications, and response to therapy.

\section{Discussion}

THE CLINICAL VARIANTS OF DEBRANCHER

DEFICIENCY MYOPATHY

On account of its phenotypic variability and the broad age range of disease onset (1 to 62 years) debrancher deficiency may be confused with a

Table 2 Debrancher deficiency myopathy: characteristics of distinct clinical phenotypes $(n=83)$

\begin{tabular}{|c|c|c|c|c|c|c|c|}
\hline Phenotype & $n(\%)$ & $\begin{array}{l}\text { Male:female } \\
\text { ratio }\end{array}$ & $\begin{array}{l}C K(x \\
\text { normal })\end{array}$ & $\begin{array}{l}\text { Slow } N C V \\
(\%)\end{array}$ & $\begin{array}{l}\text { CMP [Severe } \\
C M P]\end{array}$ & $\begin{array}{l}\text { Liver disease } \\
\text { [Severe LD] }\end{array}$ & $\begin{array}{l}\text { Response } \\
\text { to therapy }\end{array}$ \\
\hline Distal myopathy & $8(10 \%)$ & $3: 1$ & $6-33$ & $7(88)$ & $6(75 \%)[n=0]$ & $3(50 \%)[n=0]$ & N/A \\
\hline \multicolumn{8}{|l|}{ Generalised myopathy: } \\
\hline Juvenile onset & $24(29 \%)$ & $2: 1$ & $2-33$ & $2(8)$ & $12(80 \%)[\mathrm{n}=0]$ & $18(90 \%)[\mathrm{n}=1]$ & ++ \\
\hline Adult onset & $16(19 \%)$ & $4: 1$ & $10-45$ & $6(37)$ & $9(100 \%)[n=0]$ & $8(67 \%)[n=2]$ & $(+)$ \\
\hline $\begin{array}{l}\text { Myopathy of respiratory } \\
\text { muscles }\end{array}$ & $1(1 \%)$ & $0: 1$ & 5 & 0 & $1(100 \%)[n=1]$ & 0 & ++ \\
\hline Minimal variant myopathy & $34(41 \%)$ & $3: 1$ & $5-15$ & $4(12)$ & $16(76 \%)[n=3]$ & $31(94 \%)[n=3]$ & N/A \\
\hline
\end{tabular}

$\mathrm{CK}=$ creatine kinase; $\mathrm{NCV}=$ nerve conduction velocity; $\mathrm{CMP}=$ cardiomyopathy (pathological electrocardiogram and/ or echocardiography; severe $\mathrm{CMP}=$ heart failure; $\mathrm{LD}=$ liver disease; severe $\mathrm{LD}=$ cirrhosis; $\mathrm{NA}=$ data not available. 
palette of other common neuromuscular disorders and thus probably represents an underrecognised disease entity. Our patients illustrate the clinical heterogeneity of neuromuscular glycogenosis type III. Four distinct phenotypes may be differentiated based on the clinical appearance, course of disease, and rate of organ involvement (table 2).

\section{Distal myopathy}

Slowly progressive distal myopathy involving calves and peroneal muscles is a typical phenotype of neuromuscular debrancher deficiency in adult life. ${ }^{9}{ }^{10}$ Apart from late onset of disease, the usually benign (non-disabling) course, comparatively low rate of hepatic involvement, and absence of severe cardiomyopathy are characteristic of this clinical variant (table 2). Mild sensory deficits and fasciculations may accompany the myopathic complaints and arise from glycogen storage in peripheral nerves. ${ }^{21}{ }^{26}$ Actually, nerve conduction studies yielded evidence of peripheral nerve involvement in most of these patients ( $88 \%$; table 2$)$. Rarely, neuropathic damage may even be the presenting feature. $^{212627}$ In some patients the clinical appearance is indistinguishable from incipient motor neuron disease or common polyneuropathies. Myotonic dystrophy and inclusion body myositis are two muscle disorders that commonly show a distal pattern of weakness.

\section{Myopathy of respiratory muscles}

The most serious and at the same time least frequent clinical variant of neuromuscular glycogenosis type III is a selective myopathy of respiratory muscles (patient 2). This phenotype is characterised by a respiratory failure of myogenic origin and normal or near normal strength of limb muscles. The classic aetiology of a myopathy which selectively affects respiratory muscles is adult onset acid maltase deficiency. ${ }^{28}$ Besides, respiratory failure may occur as a complication or initial manifestation of myasthenia gravis, Lambert-Eaton syn-

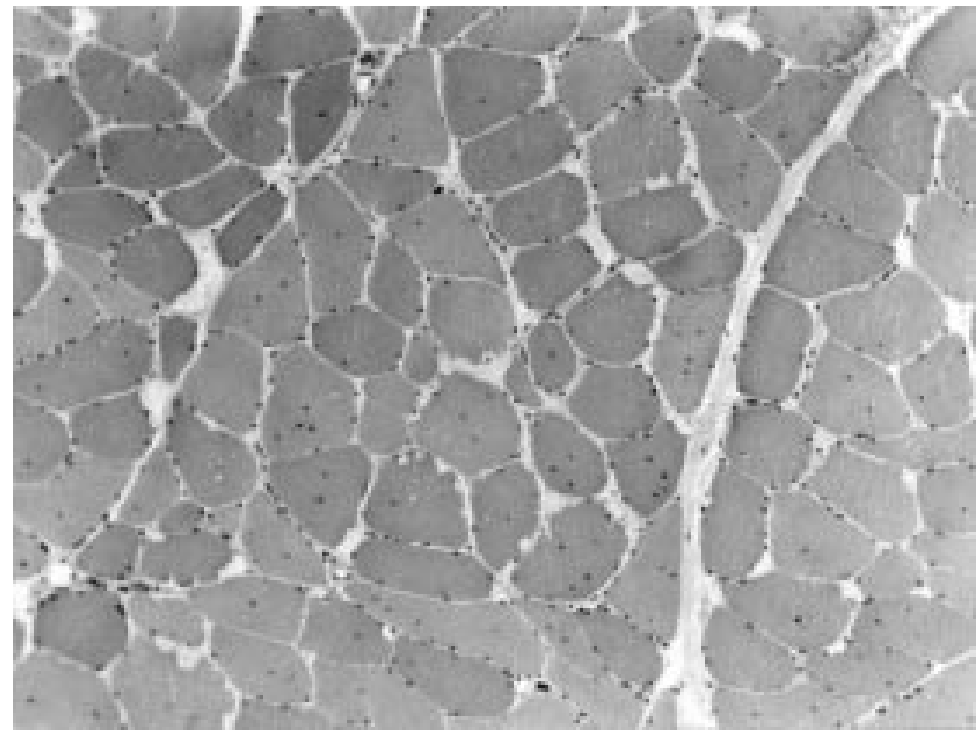

Cryostat section of muscle biopsy showing variation of fibre size, centrally located nuclei, and irregularly shaped subsarcolemal glycogen vacuoles in many fibres (hematoxylin and eosin originally $\times 120$ ). drome, atypical motor neuron disease, or sarcoid and inclusion body myositis. ${ }^{29-32}$

Fuvenile and adult onset generalised myopathy Generalised myopathies account for $48 \%$ of previously published patients with debrancher deficiency myopathy (table 2). Patients with juvenile onset of disease usually experience complete or near complete recovery around puberty and in most instances enjoy normal adult lives. ${ }^{39}$ Only in a few cases was myopathy unremitting or even progressive. ${ }^{42}$ In adult patients the generalised form of debrancher deficiency myopathy often takes a serious course. In some cases muscle weakness rapidly deteriorates, finally causing respiratory insufficiency or making the patient wheelchair bound (patient 3). Prognosis is further aggravated by comparatively high rates of advanced liver disease (table 2) or prominent neuropathy. ${ }^{12} 2127$ Unexpectedly, exercise induced muscle cramps and myalgia are uncommon and only exceptionally represent the main clinical features. ${ }^{13} 15$ A residual capacity for glucose release from peripheral chains of glycogen by the action of phosphorylase and an upregulation of alternative energy sources such as ketone bodies and fatty acids may explain this phenomenon.

Dependent on the age of onset, the list of potential differential diagnoses includes muscle dystrophies, acquired myopathies, and especially polymyositis. Polymyositis shares several clinical and laboratory features with generalised debrancher deficiency myopathy, such as (markedly) elevated creatine kinase concentrations and fibrillation activity on EMG.

\section{Minimal variant myopathy}

In patients with primarily hepatic forms of debrancher deficiency neurological examination may show mild hypotonia and proximal or generalised muscle weakness (patient 4), which is sometimes not recognised by the patients affected. As in all other types of debrancher deficiency myopathy men are more often affected than women (ratio 2-4 to 1). Cases with minimal variant myopathies have repeatedly been described in the literature (table 2). Myopathic disease expression is either reversible, stable, or only slowly progressive but may become clinically relevant at higher ages when acquired gait disorders and diseases of fibroskeletal tissues limit compensatory resources. Prognosis primarily relies on the severity of liver dysfunction or cardiomyopathy. In rare instances, the minimal disease variant may convert into a predominantly distal or progressive generalised myopathy.

The aetiology of the prominent clinical variability in debrancher deficiency has not yet been fully elucidated. There is some evidence of a tissue specific control of debrancher enzyme expression which may be subject to specific mutations. ${ }^{33}$ Apart from the well known genetic variability, ${ }^{33-35}$ environmental factors such as nutrition may achieve some relevance. ${ }^{36}$ 
LABORATORY FINDINGS

If the diagnosis of debrancher deficiency is suspected, results of several laboratory tests may offer supportive evidence such as an insufficient rise of venous lactate after standardised ischaemic exercise of the forearm (95\% of previous patients tested), a pathological glucagon test $(100 \%)$ and a "diabetic" response to a standard oral glucose challenge $(80 \%)$. Our patients and all previously published cases of debrancher deficiency myopathy had serum creatine kinase concentrations two to 45 times beyond the upper range of normal. Triglycerides, cholesterol, and urate concentrations are sometimes increased.

Electromyography may disclose pure myopathic changes $(51 \%)$, predominant neuropathic features $(6 \%)$, or a mixed pattern along with fibrillation activity (43\%). Nerve conduction studies yield variable results depending on the clinical phenotype (table 2).

Muscle biopsy shows a vacuolar myopathy sometimes superimposed by slight neurogenic atrophy. The vacuoles are strongly positive on periodic acid Schiff staining (figure) and correspond to pools of subsarcolemal glycogen not limited by membranes in electron microscopy. ${ }^{9}$ The overall content of glycogen with many short outer chains is variably raised. Biochemical analyses demonstrate a selective loss of debrancher enzyme activity. Measurement of glycogen concentrations and debrancher enzyme activity in erythrocytes or leucocytes represents a non-invasive alternative to muscle and liver biopsy and permits the correct diagnosis to be established in most cases. $^{23} 3738$

\section{INVOLVEMENT OF OTHER TISSUES}

Evidence of cardiac involvement is found in four of five patients with type III glycogenosis, with the disease expression ranging from minor ECG abnormalities without clinical relevance to severe cardiomyopathy and congestive heart failure $\left(<5 \%{ }^{17}{ }^{39}{ }^{40}\right)$. About one half of patients with adult onset debrancher deficiency myopathy have manifest liver disease or report childhood hepatomegaly, whereas in patients with juvenile manifestation of disease symptomatic liver involvement is an almost obligatory finding (table 2). Less than $10 \%$ of patients with hepatic dysfunction develop hepatoma or progressive liver cirrhosis. ${ }^{70} 41$

\section{THERAPEUTICAL APPROACHES}

A high protein diet may be efficient in reversing growth retardation and improving muscle strength in childhood glycogenosis type III. ${ }^{7}{ }^{12} 36$ Effects of dietary measures on myopathies in adults are less well established. In our series, patient 2 had subacute severe myopathy of respiratory muscles; she required prolonged mechanical respiration and recovered completely after a high protein diet. Slonim et al reported a dramatic response of generalised debrancher deficiency myopathy on administering a high protein diet in two adult patients. ${ }^{12}$

\section{Conclusions}

Debrancher deficiency myopathy is a heterogeneous disease with various distinct clinical phenotypes and age at onset ranging from 1 to 62 years. It may be regarded as a chameleon among neuromuscular disorders, capable of mimicking muscle dystrophies, inherited metabolic and acquired myopathies, polyneuropathies, and even motor neuron disease. A history of childhood hepatomegaly or hypoglycaemia or a mixed EMG pattern may help establish the correct diagnosis, whereas normal creatine kinase largely rules out this type of glycogen storage disease. The current study intends to increase awareness for this probably under diagnosed and potentially treatable disease. Most patients with juvenile onset and some patients with adult onset debrancher deficiency benefit from a high protein diet.

1 Forbes GB. Glycogen storage disease. Report of a case with abnormal glycogen structure in liver and skeletal muscle. $\mathcal{F}$ Pediatr 1953;42:645-50

2 Illingworth B, Cori GT, Cori CF. Amylo-1,6-glucosidase in muscle tissue in generalized glycogen storage disease. $\mathcal{F}$ Biol Chem 1956;218:123.

3 Howell R. The glycogen storage diseases. In: Stanbury JB,
Wyngaarden JB, Fredrickson SD, eds. The metabolic basis of inherited disease. New York: Mc Graw-Hill 1972:149-73.

4 Coleman RA, Winter HS, Wolf B, et al. Glycogen storage disease type III (glycogen debranching enzyme deficiency): correlation of biochemical defects with myopathy and cardiomyopathy. Ann Intern Med 1992;116:896-900.

5 Van Hoof F, Hers HG. The subgroups of type III glycogenosis. Eur $\mathcal{F}$ Biochem 1967;2:265-70.

6 Chen YT, He JK, Ding JH, et al. Glycogen debranching enzyme: purification, antibody characterization, and immunoblot analyses of type III glycogen storage disease. $\mathrm{Am}$ 7 Hum Genet 1987;41:1002-15.

7 Momoi T, Sano H, Yamanaka C, et al. Glycogen storage disease type III with muscle involvement: reappraisal of phenotypic variability and prognosis. Am $\mathcal{F}$ Med Genet 1992;42:696-9.

8 Hers HG, Verhue W, Van Hoof F. The determination of amylo-1,6-glucosidase. Eur f Biochem 1967;2:257-64.

9 DiMauro S, Hartwig GB, Hays A, et al. Debrancher deficiency: neuromuscular disorder in five adults. Ann Neurol 1979;5:422-36.

10 Cornelio F, Bresolin N, Singer PA, et al. Clinical varieties of neuromuscular disease in debrancher deficiency. Arch Neurol 1984;41:1027-32.

11 Brunberg JA, McCormick WF, Schochet SS. Type III glycogenosis: an adult with diffuse weakness and muscle wasting. Arch Neurol 1971;25:171-8.

12 Slonim AE, Coleman RA, Moses SW. Myopathy and growth failure in debrancher enzyme deficiency: improvement with high protein nocturnal enteral therapy. $\mathcal{F}$ Pediatr 1984;105: 906-11

13 Murase T, Ikeda H, Muro T, et al. Myopathy associated with type III glycogenosis. F Neurol Sci 1973;20:287-95.

14 Moses SW, Gadoth N, Bashan N, et al. Neuromuscular involvement in glycogen storage disease type III. Acta Paediatr Scand 1986;75:289-96.

15 Özand P, Tokatli M, Amiri S. Biochemical investigation of an unusual case of glycogenosis. F Pediatr 1967;71:225-32.

16 Oliner L, Shulman M, Larner J. Myopathy associated with glycogen deposition resulting from generalized lack of amylo-1,6-glucosidase. Clin Res 1961;9:243.

17 Rossignol AM, Meyer M, Rossignol B, et al. La myocardiopathie de la glycogenose type III. Arch Franc Pediatr 1979; 36:303-9.

18 Bröker HJ, Kuhn E, Fiehn W, et al. Glykogenose durch Amylo-1,6-glucosidase-Mangel. Myopathie als Leitbefund im Erwachsenenalter. Schweiz Med Wochenschr 1981;111: im Erw-8.

19 Talente GM, Coleman RA, Alter C, et al. Glycogen storage disease in adults. Ann Intern Med 1994;120:218-26.

20 Mineo I, Kono N, Hara N, et al. Myogenic hyperuricemia. A common pathophysiologic feature of glycogenosis types III, $\mathrm{V}$ and VII. N Engl $\mathcal{F}$ Med 1987;317:75-80.

21 Ugawa Y, Inoue K, Takemura T, et al. Accumulation of glycogen in sural nerve axons in adult-onset type III glycogenosis. Ann Neurol 1986;19:294-7.

22 Marbini A, Gemignani F, Saccardi F, et al. Debrancher deficiency neuromuscular disorder with pseudohypertrophy in two brothers. F Neurol 1989;236:418-20.

23 Cohn J, Wang P. Hauge M, et al. Amylo-1,6-glucosidase deficiency (glycogenosis type III) in the Faroe Islands. Hum Hered 1975;25:115-26.

24 Pellissier JF, de Barsy TH, Faugere MC, et al. Type III glycogenosis with multicore structures. Muscle Nerve 1979;2: $124-32$. 
25 Yang BZ, Stewart C, Ding JH, et al. Type III glycogen storage disease: an adult case with mild disease but complete 6 .

26 Powell HC, Haas R, Hall CL, et al. Peripheral nerve in type III glycogenosis: selective involvement of unmyelinated fiber Schwann cells. Muscle Nerve 1985;8:667-71.

27 Hokezu Y, Nagamatsu K, Nakagawa M, et al. An adult case of type III glycogenosis manifesting muscle hypertrophy and peripheral nerve involvement. Clin Neurol 1983;23: 473-9.

28 Rosenow EC, Engel AG. Acid maltase deficiency in adults presenting as respiratory failure. Am f Med 1978;64:48591.

29 Chalmers RM, Howard RS, Wiles CM, et al. Respiratory insufficiency in neuronopathic and neuropathic disorders. O F Med 1996;89:469-76.

30 Cohen R, Lipper S, Dantzker DR. Inclusion body myositis as a cause of respiratory failure. Chest 1993;104:975-7.

31 Dewberry RG, Schneider BF, Cale WF, et al. Sarcoid myopathy presenting with diaphragm weakness. Muscle myopathy presenting

32 De Carvalho M, Matias T, Coelho F, et al. Motor neuron disease presenting with respiratory failure. $\mathcal{f}$ Neurol Sci 1996;139:117-22

33 Shen J, Bao Y, Liu HM, et al. Mutations in exon 3 of the glycogen debranching enzyme gene are associated with glycogen storage disease type III that is differentially expressed in liver and muscle. $\mathcal{f}$ Clin Invest 1996;98:352-7.
34 Paravari R, Shen J, Hershkovitz E, et al. Two new mutations in the 3' coding region of the glycogen debranching enzyme in a glycogen storage disease type IIIa Ashken patient. F Inherit Metab Dis 1998;21:141-8.

35 Okubo $\mathrm{M}$, Horinishi A, Nakamura $\mathrm{N}$, et al. A novel point mutation in an acceptor splice site of intron 32 (IVS32 A-12 G) but no exon 3 mutations in the glycogen debranching enzyme gene in a homozygous patient with glycogen storage disease type IIIb. Hum Genet 1998;102:1-5.

36 Slonim AE, Weisberg C, Benke P, et al. Reversal of debrancher deficiency myopathy by the use of high-protein nutrition. Ann Neurol 1982;11:420-2.

37 Van Hoof F. Amylo-1,6-glucosidase activity and glycogen content of the erythrocytes of normal subjects, patients with glycogen storage disease and heterozygotes. Eur 7 Biochem 1967;2:271-4.

38 Maire I, Baussan C, Moatti N, et al. Biochemical diagnosis of hepatic glycogen storage diseases: 20 years French of hepatic glycogen storage diseases: 20
experience. Clin Biochem 1991;24:169-78.

39 Carvalho JS, Matthews EE, Leonard JV, et al. Cardiomyopathy of glycogen storage disease type III. Heart Vessels 1993; 8:155-9.

40 Smit GPA, Fernandes J, Leonard JV, et al. The long-term outcome of patients with glycogen storage disease. F Inherit Metab Dis 1990;13:411-8.

41 Haagsma EB, Smit GP, Niezen-Koning KE, et al. Type IIIb glycogen storage disease associated with end-stage cirrhosis and hepatocellular carcinoma. The liver transplant group. Hepatology 1997;25:537-40. 